\title{
Implications of climate change on Glacier de la Plaine Morte, Switzerland
}

\author{
M. Huss, A. Voinesco, and M. Hoelzle \\ Department of Geosciences, University of Fribourg, Fribourg, Switzerland \\ Correspondence to: M. Huss (matthias.huss@unifr.ch)
}

Received: 15 May 2013 - Revised: 19 August 2013 - Accepted: 1 October 2013 - Published: 16 December 2013

\begin{abstract}
Changes in Switzerland's climate are expected to have major impacts on glaciers, the hydrological regime and the natural hazard potential in mountainous regions. Glacier de la Plaine Morte is the largest plateau glacier in the European Alps and thus represents a particularly interesting site for studying rapid and far-reaching effects of atmospheric warming on Alpine glaciers. Based on detailed field observations combined with numerical modelling, the changes in total ice volume of Glacier de la Plaine Morte since the 1950s and the dynamics of present glacier mass loss are assessed. Future ice melt and changes in glacier runoff are computed using climate scenarios, and a possible increase in the natural hazard potential of glacier-dammed lakes around Plaine Morte over the next decades is discussed. This article provides an integrative view of the past, current and future retreat of an extraordinary Swiss glacier and emphasizes the implications of climate change on Alpine glaciers.
\end{abstract}

\section{Introduction}

Glaciers are known as one of the most direct indicators of climatic change (e.g. Haeberli and Beniston, 1998). They react sensitively to small variations in air temperature and precipitation, and their retreat is iconic for the recently observed global warming trend (Oerlemans, 2001). Glacier mass loss in the European Alps is expected to have serious consequences for the hydrological regime (Huss, 2011; Finger et al., 2012), and thus water supply in dry Alpine valleys as well as future hydropower production (Schaefli et al., 2007). Furthermore, an increase in the frequency of natural hazards in mountainous regions, such as rock face instabilities or flooding events, has been observed over the last decades (e.g. Huggel et al., 2012), and significant impacts of a diminishing glacier area on winter and summer tourism are likely (Bürki et al., 2003; Fischer et al., 2011). A combination of field measurements and model approaches is required to understand the governing processes that determine future glacier changes and the related impacts on the environment. Specific case studies on individual glaciers are necessary for better understanding the implications of climate change on the high-Alpine environment.
Glacier de la Plaine Morte, located on the main water divide between the Rhine and Rhone in the Bernese Alps, is highly particular in different aspects. Plaine Morte is the largest plateau glacier in the European Alps; almost its entire surface area shows no significant topographic gradients. Dye tracer experiments have shown that a considerable fraction of the meltwater is drained southwards to the Rhone Valley through subsurface conduits in the karstic system although the glacier surface is entirely located in the drainage basin of the Rhine River (Finger et al., 2013). A potential future change in the water supply due to glacier mass loss is a major concern in the summer-dry region around Crans-Montana, Valais, which is studied in the frame of the interdisciplinary project MontanAqua (Weingartner et al., 2010; Schneider and Homewood, 2013). Glacier de la Plaine Morte represents the top of the hydrological system. Snowand ice melt provides vital water input during the summer months which is used for hydropower production, irrigation, and private water use (Reynard and Bonriposi, 2012). The glacier is also an important touristic factor for recreational activities in winter and summer and can be accessed via a cable car from Crans-Montana. Moreover, since 2011, the outburst of several glacier-dammed lakes around Plaine 
Morte is documented causing floods in the Simme Valley on the Bernese side (Hählen, 2012). Plaine Morte is thus an ideal testing case for an integrative assessment of various economic and environmental implications of future glacier changes.

Glacier de la Plaine Morte has already received considerable attention in glaciological literature. In the 1940s, Süsstrunk (1951) was a pioneer in applying seismic methods for the determination of ice thickness, and Glacier de la Plaine Morte was one of the first sites where this new technology was tested. Studies focusing on the chemical composition of the ice (Schotterer et al., 1977), and the drainage of meltwater through the subglacial karst were carried out (Maire, 1978). More recently, the surface energy balance (Huwald et al., 2009, 2012; Bou-Zeid et al., 2010), and the ice surface albedo (Paul et al., 2005; Bühlmann, 2011) were investigated. Since 2010, Plaine Morte is subject to glaciological field studies related to the MontanAqua project. Different types of measurements were performed in order to characterize the present state of the glacier, to understand its response to past, present and future climatic forcing, and to assess its hydrological importance.

This paper highlights different aspects of the response of Glacier de la Plaine Morte to climate change. We present results of a detailed ice thickness mapping, recent changes in snow accumulation and ice melt based on in situ measurements, and a reconstruction of glacier change since the 1950s. Future glacier retreat and the consequent impacts on the runoff regime are investigated using a glacio-hydrological model. We also present a new approach to estimate temporal changes in the volume and the shape of ice-dammed lakes over the next decades, and discuss the implications on the hazard potential of glacier lakes on Plaine Morte for downstream communities. This study thus provides an integrative assessment of past and future changes in a large Swiss glacier which is particular in many ways.

\section{Study site and field data}

Glacier de la Plaine Morte currently has an area of $7.88 \mathrm{~km}^{2}$. More than $90 \%$ of its surface lies between 2650 and $2800 \mathrm{~m}$ a.s.l. which emphasizes the narrow altitude range occupied by the glacier (Fig. 1a). From the $5 \mathrm{~km}$ wide plateau with an average slope of less than $4^{\circ}$, a small glacier tongue, termed Rezligletscher, flows northwards. There is no separation between the accumulation and the ablation area. In most years, the entire glacier is snow-covered or completely snow-free at the end of summer, i.e. the equilibrium line either lies above or below the glacier. Ice flow speed seems to be very limited and some crevasses are only observed on Rezligletscher. Glacier surface structures, such as large circular depressions, probably related to cryo-karst (Maire, 1978), are stable over several decades (Fig. 1a).
Considerable parts of the glacier surface are impermeable to water flow which is related to the absence of significant glacier dynamics. Meltwater thus accumulates in surface streams reaching lengths of up to $1 \mathrm{~km}$ and is routed to large and temporally stable moulins that conduct water vertically through the ice. Whereas most meltwater is drained along the glacier bed to the north and reappears at the tongue of Rezligletscher, a significant fraction of surface melt from the western part of Plaine Morte enters the karstic system that is connected to the Rhone Valley through subsurface conduits (Finger et al., 2013). The meltwater thus crosses the main surface water divide.

Since several years, three glacier-marginal lakes around Plaine Morte are observed. Strubelsee and Lac de Vatseret are rather small; Lac des Faverges at the south-western margin of the glacier (Fig. 1a) currently has a considerable water volume of about $1.5 \mathrm{Mm}^{3}$ (million cubic metres) (Hählen, 2012). All lakes form on impermeable sediments and are dammed by the ice on one side, thus making them potentially instable. Until 2011, no outbursts were documented (although smaller events might have gone unnoticed), and the lakes filled until the water level reached a surface overflow. In 2011-2013, however, some lakes were subject to subglacial drainage within a few days in early summer (Hählen, 2012).

The ice thickness of Glacier de la Plaine Morte was measured in a 2 day field campaign in February 2010. About $20 \mathrm{~km}$ of tracks with a ground penetrating radar (GPR) system were achieved, covering the entire glacier (Voinesco, 2012). GPR is a standard method to determine the ice thickness of Alpine glaciers and is based on the reflection of electromagnetic waves at the ice-bedrock interface (e.g. Macheret et al., 1993; Bauder et al., 2003). We used a GPR system by Måla and a rough-terrain antenna with a frequency of $25 \mathrm{MHz}$. Data quality was excellent in the southern and western part of the glacier. In the north and east however, bedrock reflections were partly unclear, probably due to absorption by englacial water or noise due to crevasses (Voinesco, 2012).

Seasonal mass balance measurements for the four hydrological years 2009/2010-2012/2013 have been carried out based on the direct glaciological method. A network of ablation stakes (Fig. 1a), placed in the ice using a steam drill, was surveyed 2-4 times over the summer season, providing monthly measurements of snow and ice ablation. At least four stakes were measured in every year. Observed ablation varies within a relatively small range. We thus assume that the limited number of measurement sites is sufficient for capturing the mass balance of the entire glacier. We measured winter accumulation in mid-April based on 100-200 snow probings (depending on the survey year) distributed over the entire glacier surface. Snow density was determined in 1-2 snow pits. The extrapolation of accumulation and ablation measurements is supported by a spatially distributed glacier mass balance model including the influence of direct solar radiation and wind redistribution (Huss, 2010). This 


\section{Glacier de la Plaine Morte}

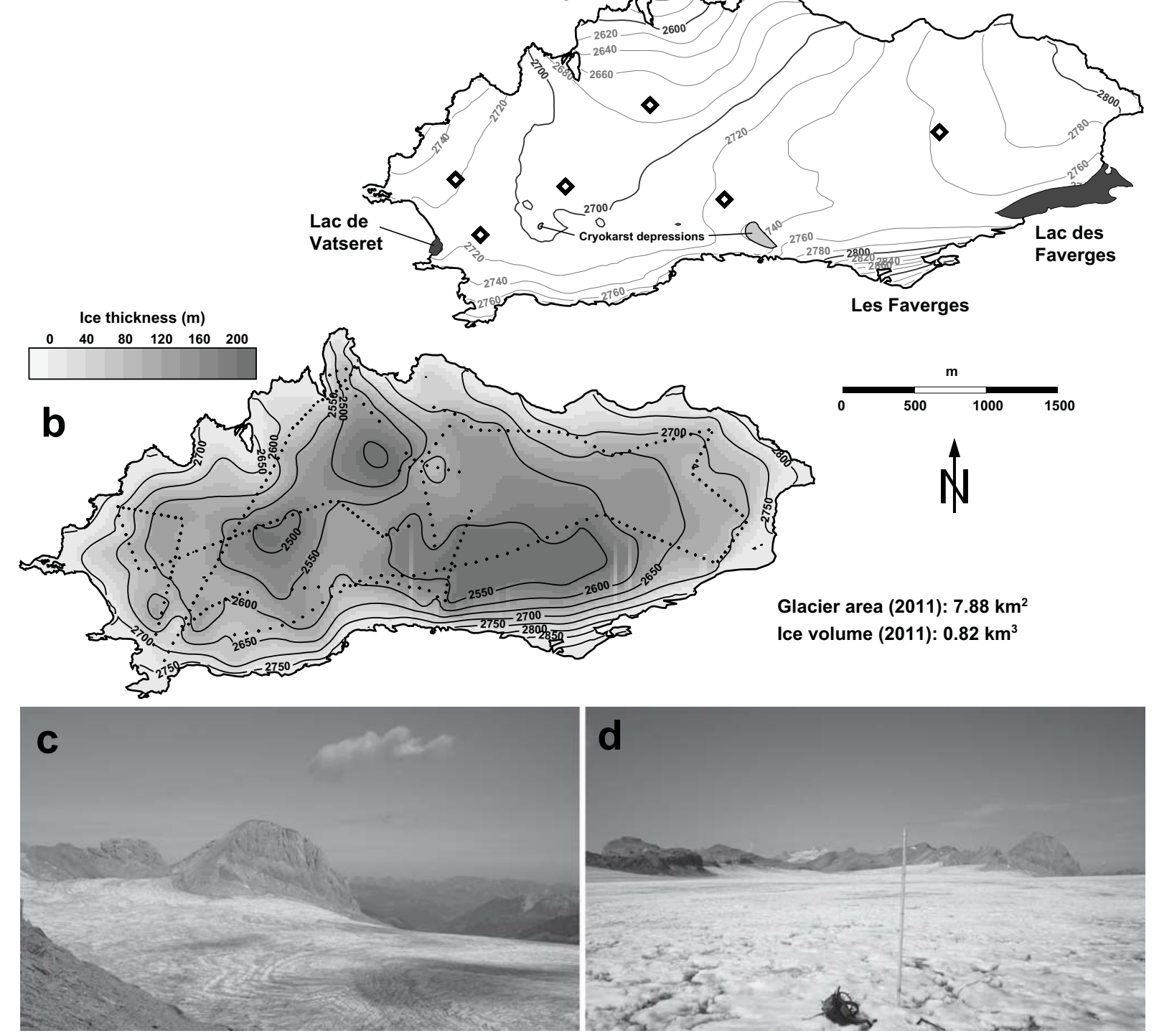

Figure 1. (a) Map of Glacier de la Plaine Morte with surface topography in 2011. The position of mass balance measurement sites (diamonds), cryo-karst depressions, and ice-marginal lakes is indicated. (b) Ice thickness distribution of Glacier de la Plaine Morte with GPR measurement tracks. Contours show bedrock elevation. (c, d) Overview photographs of Glacier de la Plaine Morte.

allows calculating the seasonal glacier volume change in water equivalent (w.e.).

Information on glacier surface geometry is obtained from a digital elevation model (DEM) acquired in 2011 based on a photogrammetrical evaluation of aerial photographs (kindly provided by Oberingenieurskreis I, Thun). Another DEM for the year 1954 was established by digitizing contour lines of the first topographic map in the $1: 25000$ scale (Voinesco, 2012). Both DEMs were interpolated to a $25 m \times 25 \mathrm{~m}$ grid and are accompanied by a mapping of the glacier outline. Additional high-resolution aerial photographs from Swisstopo from the years 2000, 2007 and 2010 are available providing evidence on short-term changes in glacier extent and ice surface features.

Meteorological data are provided by MeteoSwiss weather stations at Montana (1495 ma.s.l., at $8 \mathrm{~km}$ from the glacier) and at Adelboden (1320 ma.s.l., $13 \mathrm{~km})$. We use daily air temperature and precipitation. In addition, long-term weather data from the homogenized series at Sion (542 ma.s.l., $20 \mathrm{~km}$ ) were used.

\section{Ice thickness}

The ice thickness distribution and the volume of a glacier determine its response to climate change and its importance to 
local and regional hydrology (e.g. Huss et al., 2008b; Gabbi et al., 2012). The favourable accessibility of Plaine Morte allowed us to cover the entire glacier with the ice thickness survey thus providing complete information on subglacial bedrock topography (Fig. 1b).

GPR signals were treated and enhanced using standard processing methods (Voinesco, 2012). Bedrock reflections on the GPR tracks were converted to ice thickness by assuming a radio wave velocity of $0.169 \mathrm{~m} \mathrm{~ns}^{-1}$ in temperate ice (e.g. Macheret et al., 1993; Blindow et al., 2010). Measured thickness along the GPR profiles was subsequently interpolated in space. We also used ice thickness estimates by Süsstrunk (1951) based on seismic surveys for the interpolation.

A total ice volume of $0.82 \pm 0.1 \mathrm{~km}^{3}$ is inferred for 2011 (Fig. 1b). The mean ice thickness of Glacier de la Plaine Morte is $104 \mathrm{~m}$, the maximum thickness detected is $226 \pm$ $18 \mathrm{~m}$. The uncertainty in total ice volume is estimated based on the accuracy and the spatial representativeness of the radio-echo sounding profiles, and the quality of the bedrock reflections. Compared to the size of Plaine Morte, the ice volume is considerable and corresponds to almost $1.5 \%$ of the glacier volume (updated to 2011) in the Swiss Alps (Farinotti et al., 2009). The interpolated bedrock shows several depressions in the southern part of the glacier. The shape of the subglacial topography slightly resembles a bathtub (Fig. 1b). A ridge with smaller ice thicknesses separates the deepest regions from the glacier tongue. It is however difficult to judge from the direct measurements whether lakes might form in these bedrock depressions after the complete disintegration of the ice. The depressions might be drained through water channels in the karst (Finger et al., 2013), or they might be connected by valleys in the bedrock that could not be detected by the relatively coarsely spaced GPR measurements.

\section{Glacier mass balance}

The direct mass balance measurements for the hydrological years 2009/2010-2012/2013 indicate that Glacier de la Plaine Morte currently is in a state of disequilibrium with strongly negative mass balance. One of the ski lifts on Plaine Morte had to be recently closed down due to glacier recession, and the installations of the other lift are artificially dismantled in order to warrant mechanical stability. Over the last four years, almost the entire glacier was snow-free by the end of the summer. In order to maintain an equilibrium, at least $66 \%$ of the glacier surface would need to be covered with winter snow by September (Gross et al., 1977). Presently, three positive feedback effects further accelerate glacier mass loss. (1) As the glacier is snow-free, bare ice with a lower surface albedo is exposed. This leads to increased absorption of solar radiation, and thus enhanced melt (Paul et al., 2005; Bühlmann, 2011). (2) With negative mass balances the glacier surface continuously lowers and is thus exposed to progressively warmer air temperatures. (3) With

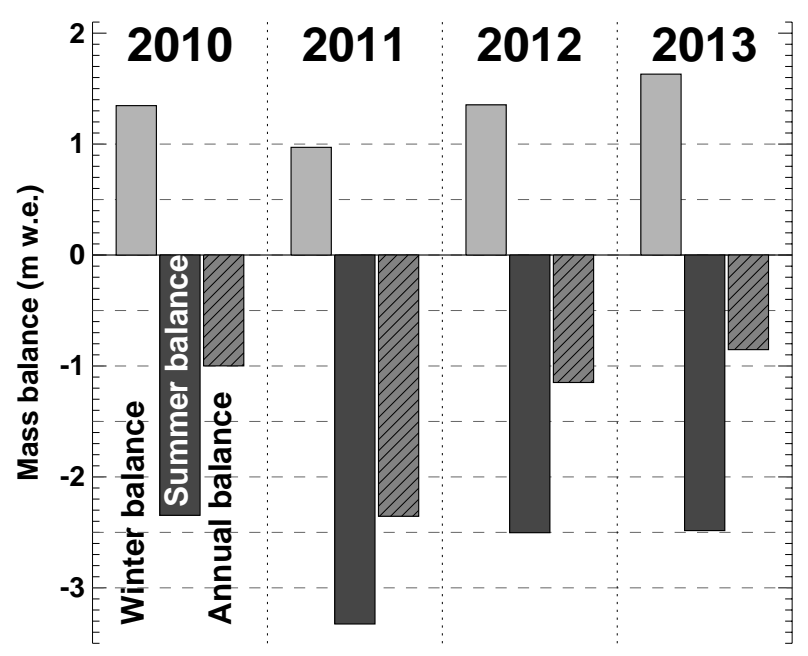

Figure 2. Measured seasonal mass balance of Glacier de la Plaine Morte for the hydrological years 2009/2010-2012/2013.

glacier retreat bedrock or sediments with low albedo are revealed affecting local air temperatures. As Plaine Morte does not extend beyond $2900 \mathrm{~m}$ a.s.l., the glacier cannot retreat to higher elevations in order to reach a new balance with the modified climatic conditions. The current ice wastage is thus a self-amplifying process. With its current geometry, the glacier could not stabilize over the next decades even with a more glacier-friendly climate than today.

Although Glacier de la Plaine Morte exhibits a very homogenous surface topography, some significant variations in winter snow depth persisted for the last years. Whereas snow accumulation is maximal in a band from the summit of Les Faverges to the glacier tongue, less snow is found in the east and the west of the glacier. These variations are attributed to preferential snow deposition related to the movement of the air masses and subsequent redistribution of unconsolidated snow by wind (e.g. Lehning et al., 2008).

Compared to the quantities of winter precipitation recorded at Montana and Adelboden, the difference in snow water equivalent deposited on Plaine Morte is considerable. On average, more than five times (Montana), and three times (Adelboden) higher accumulation is found on the glacier. Plaine Morte is situated on the main water divide and receives precipitation from the north as well as from the west resulting in a strong amplification of precipitation with elevation. In addition, strong winds tend to erode snow on the surrounding mountain flanks and deposit it on the glacier.

The spatial distribution of glacier mass balance remains similar throughout the years. The most negative mass balances are found in the east of the glacier (likely explained by smaller snow accumulation), in the west (due to very low surface albedo, see Bühlmann, 2011), and on the glacier tongue (lower elevation, and thus higher air temperatures). However, generally, surface mass balance shows small variations 
Surface elevation change 1954-2011 (m) $\begin{array}{llllllll}-70 & -60 & -50 & -40 & -30 & -20 & -10 & 0\end{array}$
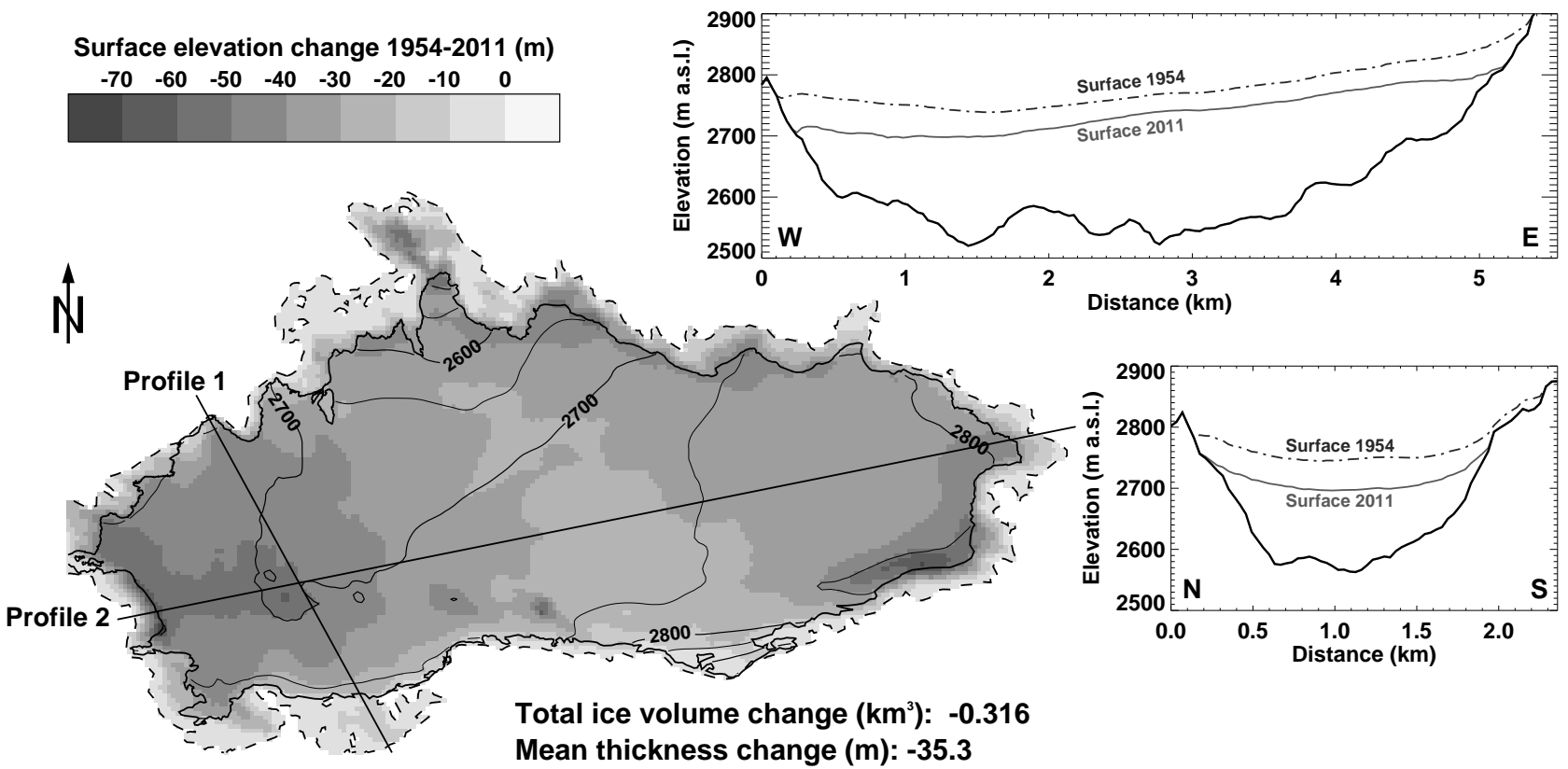

Mean thickness change $(\mathrm{m}):-35.3$

Figure 3. Observed glacier surface elevation changes between 1954 and 2011. Two cross-profiles are shown in the insets.

in space compared to a typical Alpine glacier and measuring ablation at a few index sites only (Fig. 1a) has proven to be well suited to characterize the mass change of the entire glacier.

Winter mass balance was $+1.35 \mathrm{~m}$ w.e. in 2010 and 2012 (Fig. 2), corresponding to a mean snow depth of 3-4 m. In 2011, significantly smaller accumulation was observed, contributing to an early depletion of the winter snow. Annual mass balance was similar in 2010 and 2012, with -1.0 and $-1.1 \mathrm{~m}$ w.e., respectively (Fig. 2 ), corresponding to a loss in glacial water storage of about $8 \mathrm{Mm}^{3}$. Glacier ice wastage in the year 2011 was extreme with a mass balance of $-2.4 \mathrm{~m}$ w.e. The strong mass loss in 2011 is explained by the reduced winter accumulation, the hot spring leading to a complete disappearance of the protecting snow coverage already in the beginning of July, and the phase of excellent weather conditions with stable high pressure cells lasting throughout August and September. In total, almost $3 \%$ of the total ice volume of Plaine Morte, or $18.3 \mathrm{Mm}^{3}$ of water, was removed during 2011, providing a scenario for conditions to come in the next decades. A slightly less negative mass balance ( $-0.8 \mathrm{~m}$ w.e.) was observed despite high summer temperatures in the hydrological year 2012/2013 which is attributed to enhanced snow accumulation in winter and spring (Fig. 2).

By differencing the DEMs of 1954 and 2011 (see e.g. Bauder et al., 2007), surface elevation changes over the $57 \mathrm{yr}$ period, and the total ice volume loss were determined (Fig. 3). Glacier ice thickness has decreased by $35 \mathrm{~m}$ over the last six decades on average, with maximum values of $70 \mathrm{~m}$. The spatial distribution of surface elevation changes correlates with observed surface mass balance distribution supporting the hypothesis that ice flow dynamics are almost negligible on Plaine Morte. Glacier area has been reduced from $10.0 \mathrm{~km}^{2}$ in 1954 to $7.88 \mathrm{~km}^{2}$ in 2011 , corresponding to a relative area change of $-21 \%$. Unlike for typical Alpine glaciers, the area loss is not primarily concentrated at the glacier tongue but is distributed around the entire glacier; a significant reduction in glacier area was also observed in the accumulation area (Fig. 3). The length change of the glacier tongue, measured since almost one century (Glaciological reports, 1881-2011), is therefore relatively small despite the strong glacier mass loss. Ice volume has decreased from $1.14 \mathrm{~km}^{3}$ (1954) to $0.82 \mathrm{~km}^{3}$ in 2011 corresponding to a reduction of $28 \%$.

Using an accumulation-melt model (Hock, 1999; Huss et al., 2008a), annual mass balance of Glacier de la Plaine Morte was calculated based on long-term daily meteorological series from Sion. The model was calibrated on the observed ice volume change, 1954-2011 (Fig. 3), and the spatial mass balance distribution was validated using the in situ measurements since 2009.

The mass loss of Plaine Morte is more rapid compared to the mean of glaciers in the European Alps (Fig. 4). Longterm Alpine-wide mass balance series have been inferred from a statistical extrapolation of all available measurements (Huss, 2012). Interestingly, Plaine Morte was close to equilibrium between 1960 and 2002. However, glacier melt in the late $1950 \mathrm{~s}$ and over the last $10 \mathrm{yr}\left(-1.7 \mathrm{~m}\right.$ w.e. $\mathrm{yr}^{-1}$ on average) was almost double compared to the Alpine average. We explain this particular behaviour of Glacier de la Plaine Morte with its limited altitudinal range. The glacier 


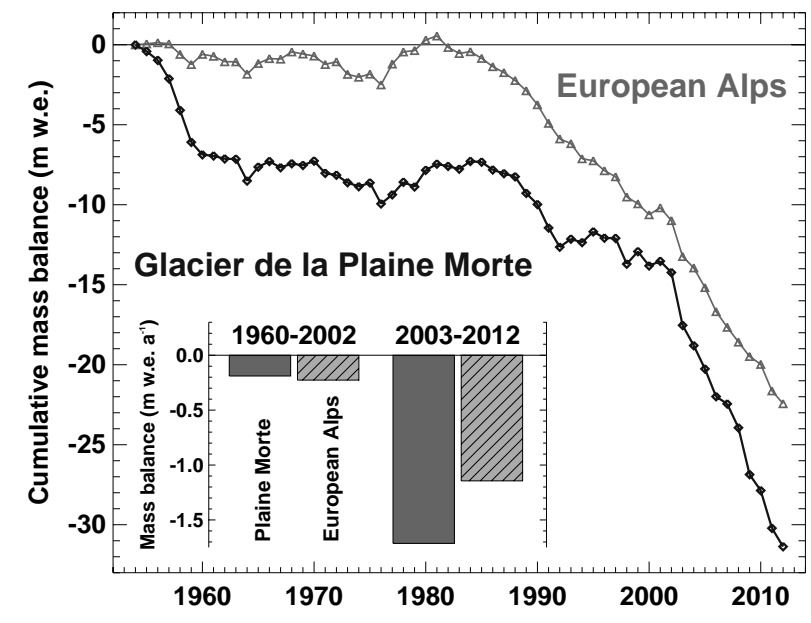

Figure 4. Cumulative mass balance of Glacier de la Plaine Morte since 1954 compared to the average of the European Alps (Huss, 2012). The inset shows mean mass balance in two periods.

is either completely snow-covered or snow-free at the end of the hydrological year. The albedo feedback effect is thus highly significant in shaping mass balance variations. Due to its particular geometry, the sensitivity of Glacier de la Plaine Morte to only minor shifts in climatic forcing (e.g. increased summer temperatures or reduced snow falls) is strongly enhanced, which also leads to an amplification of its response to future atmospheric warming.

\section{Future glacier retreat and runoff}

Glacier evolution over the 21 st century and consequent impacts on the runoff regime was investigated using the glaciohydrological model GERM (Huss et al., 2008b). Based on daily temperature and precipitation data this model computes the components of the water balance (i.e. snow and ice melt, quick and slow flow, evaporation). 3-D glacier surface geometry is updated in annual time steps based on a simple mass conserving parameterization scheme. Scenarios of future climate are provided by the ENSEMBLES project (van der Linden and Mitchell, 2009). Monthly changes in meteorological variables for the study region are given by 10 regional climate models (RCMs) (Bosshard et al., 2011). By 2100, the median scenario describes a mean annual air temperature increase of $4.2^{\circ} \mathrm{C}$ relative to the period 1980-2009. Summer temperature increase is most pronounced, and there is a general trend towards reduced precipitation in summer and more snowfall in wintertime.

The glacier model is run using the parameters calibrated to field data and is initialized with the glacier surface geometry of 2011. The results indicate a strong lowering of the ice surface over the next decades. Glacier area change is however delayed (Fig. 5). According to the median scenario, Glacier de la Plaine Morte will still have a size of about $4 \mathrm{~km}^{2}$ by the year 2060 but a $86 \%$ reduction in ice volume relative to 2011 is computed. Glacier evolution is determined by the process of non-dynamic downwasting, i.e. the glacier is not retreating to higher elevations, but is just melting down due to its geometrical constraints (Fig. 5). By about 2080 a complete disintegration of Plaine Morte is likely with some dead ice patches remaining at the locations with the currently thickest ice.

However, the uncertainties regarding the modelling of glacier evolution over the 21 st century are considerable. This is due to unknown future changes in the climate system, as well as some poorly represented feedback effects in the modelling of glacier mass balance. We have calculated the fate of Glacier de la Plaine Morte with temperature and precipitation changes provided by 10 different RCMs. Although all climate models are driven by the same $\mathrm{CO}_{2}$-emission scenario, calculated rates of glacier area change show considerable differences (Fig. 6). Relative to today, the RCM prescribing the largest air temperature increase expects an area loss of $97 \%$ by 2060 , compared to only $31 \%$ for the best-case climate scenario.

Future changes in stream-flow runoff from the basin of Glacier de la Plaine Morte were calculated with the combined model for glacier retreat and catchment water balance (GERM, Huss et al., 2008b). Consistent with a number of studies on the 21 st century discharge changes in glacierized drainage basins (e.g. Braun et al., 2000; Farinotti et al., 2012; Bavay et al., 2013), a significant increase in annual runoff volume is found for the next decades. This is explained by the release of water from long-term glacial storage, i.e. negative glacier mass balances. After reaching a maximum between about 2040 and 2060, runoff strongly decreases as the shrinking glacier area can no longer provide large quantities of additional meltwater. After the complete demise of the glacier, the annual runoff converges to the precipitation sum that is not expected to change significantly over the 21 st century. The decrease in total runoff volume is thus limited compared to the present situation. The changes for the summer months, however, are substantial. Whereas discharge in July and August shows a considerable increase until 2060, masking out any potential future water scarcity, there is a sharp regime shift between 2060 and 2080, which is explained by a strong glacier retreat due to an almost complete exhaustion of the glacial water reservoir (Fig. 7). A reduction in August runoff of $83 \%$ is evident between 2040 and 2100. This trend might represent a serious problem in dry Alpine valleys, as there water is most urgently needed during the summer months. Conversely, an increase in runoff from the basin of Glacier de la Plaine Morte is expected for winter, spring and autumn towards the end of the 21st century (Fig. 7). Although the present partitioning of glacial meltwater from Glacier de la Plaine Morte between the Rhine and the Rhone has been investigated in detail (Finger et al., 2013), inferring future fractions of water draining north, or south through channels in the karst is difficult and highly uncertain. 

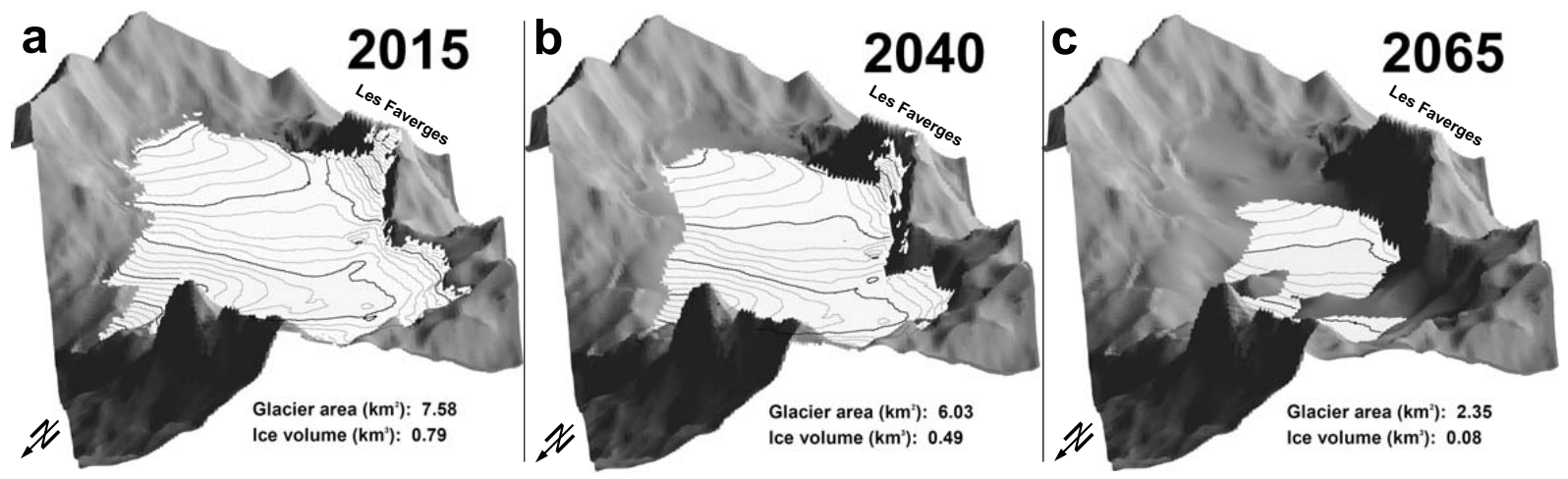

Figure 5. Calculated retreat of Glacier de la Plaine Morte.

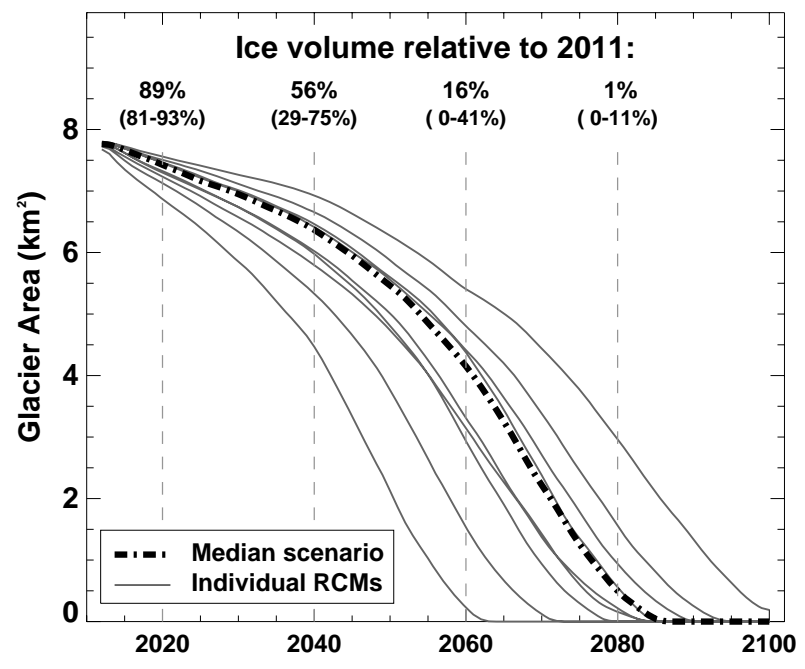

Figure 6. Calculated changes in future glacier area based on 10 RCMs. The ice volume relative to 2011 is given (mean and range).

\section{Glacier-dammed lakes}

Ice-dammed lakes around Plaine Morte (Fig. 1a) represent a considerable hazard potential for the Simme Valley north of the glacier. The floods of 2011 and 2012 occurred in late July. Fortunately they did not cause any destruction. Whereas the drainage of Lac de Vatseret seemed to be linked with the outburst of Lac des Faverges, the largest lake on Plaine Morte, in 2011 and 2012, the filling and emptying of Strubelsee is probably decoupled (Hählen, 2012). River discharge in the Simme increased by a factor of more than 2 within only 1 day during the outburst of Lac des Faverges in 2012. A real-time monitoring of all glacier lakes set up by the local authorities is in place and is operational for early warning (Hählen, 2012). This chapter will not enter the processes and dynamics involved in the lake outburst events that yet remain to be investigated in more detail but provides some tentative trends for the possible future evolution of Lac des Faverges, the largest ice-dammed lake on Plaine Morte.

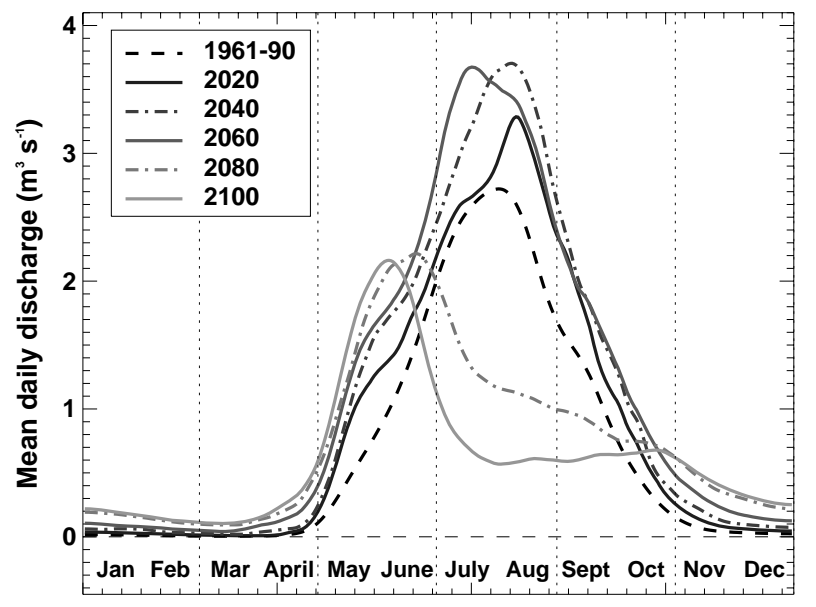

Figure 7. Future changes in the runoff regime in the drainage basin of Glacier de la Plaine Morte. The average for the period 1961-1990 is shown.

Lac des Faverges is filled up annually. Meltwater accumulates in the lake basin after the onset of the melting season. After reaching a maximum level of $2752 \mathrm{~m}$ a.s.l., lake water was drained over a stable superficial channel in the moraine deposits towards the Tièche basin south of the glacier before 2012. With the glacier mass loss of the last years, the lake basin has been progressively enlarged, thus increasing the hazard potential. The surface area of Lac des Faverges has grown by more than $50 \%$ between 2007 and 2011 to $0.13 \mathrm{~km}^{2}$ according to aerial photographs (Fig. 9a).

The future evolution of Lac des Faverges will determine the need for additional downvalley protection measures. With the ongoing wastage of Glacier de la Plaine Morte the further growth of the lake in the next years and decades is probable. The modelled change in 3-D ice surface geometry according to the median climate scenario (Fig. 5), and the bedrock elevation obtained from the GPR measurements (Fig. 1b) provide the basis for assessing future changes in lake geometry and volume. By completely filling the simulated lake basin for each year in the period 2011-2050 until an overflow 


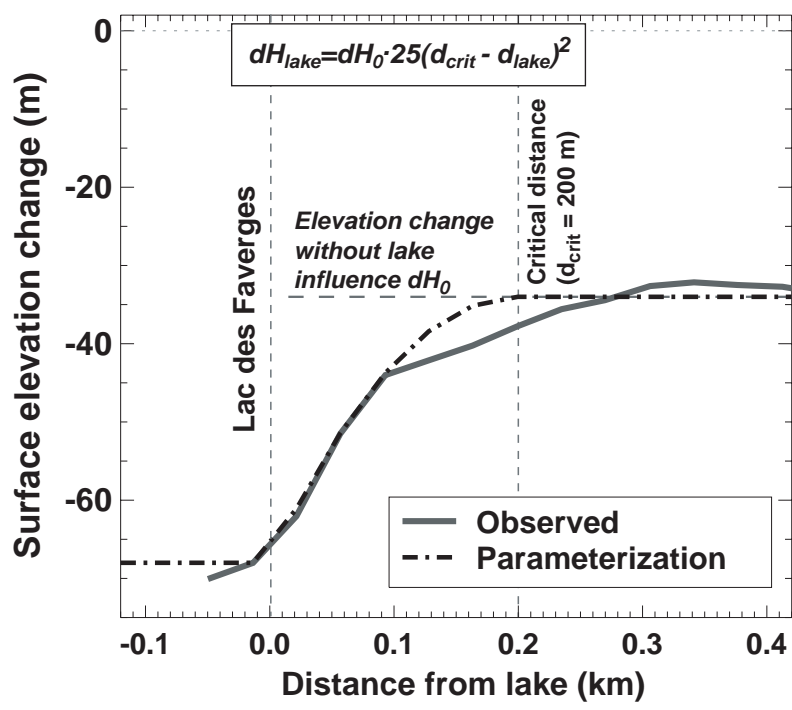

Figure 8. Observed amplification of ice surface lowering between 1954 and 2011 for a profile at Lac des Faverges (Fig. 1a). The empirical function used to simulate future growth of the lake basin is shown, and parameters are given.

either to the south or to the north/west is reached, we calculate the shape and the potentially stored water volume of Lac des Faverges. An important factor that needs to be accounted for in this evaluation is the effect of lake water on local ice surface elevation change. An increase in ice flow speed and calving rate triggering a subsidence of the glacier surface has been reported for glaciers in contact with freshwater lakes (Funk and Röthlisberger, 1989; Tsutaki et al., 2011). This factor is not included in the modelled glacier retreat using GERM and needs to be added. We apply a simple approach based on observed ice surface elevation changes on Plaine Morte. Between 1954 and 2011, surfaces close to the glacier lakes have been subject to stronger lowering compared to areas unaffected by the presence of a lake (Fig. 3). Based on this direct observational evidence it was found that ice thickness loss is enhanced by a factor of roughly 2 in the lake basins over long timescales (Fig. 8). This evidence is used to define a simple empirical relation that allows calculating the local amplification of typical surface lowering due to negative mass balance as a quadratic function of the distance to the lake (Fig. 8).

We expect major changes in Lac des Faverges over the next decades leading to (i) a decrease in maximal lake level, (ii) a westward shift of the lake by almost $1 \mathrm{~km}$, and (iii) a significant increase in potential volume (Fig. 9). Due to the projected lowering of the glacier, the surface overflow to the Tièche basin has already been deactivated in 2013 (I. Kull, personal communication, 2013) and all lake water will drain towards the Simme Valley. Our model indicates a rapid growth of the lake at its western shore (Fig. 9a) and a lowering of the maximal lake level of $2-3 \mathrm{~m} \mathrm{yr}^{-} 1$ (Fig. 9b, c), corresponding to the calculated annual glacier mass balance. Due to accelerated recession of the glacier margin from the mountain flank confining Plaine Morte to the south, the potential lake volume is expected to simultaneously grow and to reach more than $8 \mathrm{Mm}^{3}$ by 2050. A complete filling of this large basin is however unlikely as the annual runoff yield of the lake catchment is barely sufficient. According to our analysis the lake basin will be rapidly reduced after 2050 as the ice dam is subject to strong lowering.

The uncertainties in the projections of Lac des Faverges are high, as (1) the rate of glacier retreat (Fig. 6), (2) the ice melt dynamics close to the lake (Fig. 8), and (3) the future changes in the subglacial hydrological system are difficult to estimate. The configuration of the drainage system (3) determines whether meltwater is actually trapped in the lake basin in spring, or if the sub- or englacial drainage channels remain open throughout the winter season (e.g. Röthlisberger, 1972; Werder et al., 2010). A potentially dangerous glacier lake could only form with the condition of a seasonally impermeable ice dam. Continued monitoring of the ice-dammed lakes around Plaine Morte is required to ensure the early recognition of a hazardous lake evolution.

\section{Conclusions}

Glacier de la Plaine Morte is highly vulnerable to small changes in climatic forcing due to its limited altitude range. Using various field data and modelling approaches the implications of climate change on this remarkable glacier was assessed and perspectives for future adaptive measures in response to glacio-hydrological impacts are provided. Our study indicates that Glacier de la Plaine Morte is currently in a state of strong disequilibrium with average ice volume losses of more than $10 \mathrm{~m}^{3} \mathrm{yr}^{-1}$. Although winter snow accumulation on the glacier can be up to five times higher than corresponding precipitation sums at the nearby mountain flanks of the Rhone Valley, snow coverage on the glacier has been completely depleted by the beginning of August in recent years. This causes a significant albedo feedback that further enhances glacier melt. We interpret this effect as the reason for the more sensitive climate change response of Glacier de la Plaine in comparison to other Alpine glaciers. Climate scenarios indicate that the presently more than $200 \mathrm{~m}$ thick ice of Plaine Morte will have entirely melted by the end of this century. This will have serious consequences on the hydrological regime with a strong decrease in runoff yield during the summer months. Over the next decades an increase in the hazard potential due to rapid drainage of icedammed lakes around Glacier de la Plaine Morte is likely, and requires a continuation of the ongoing monitoring efforts on glacier lakes.

Despite the wealth of data collected on Glacier de la Plaine Morte and the application of different model approaches to assess future glacier changes, the uncertainties in projected 

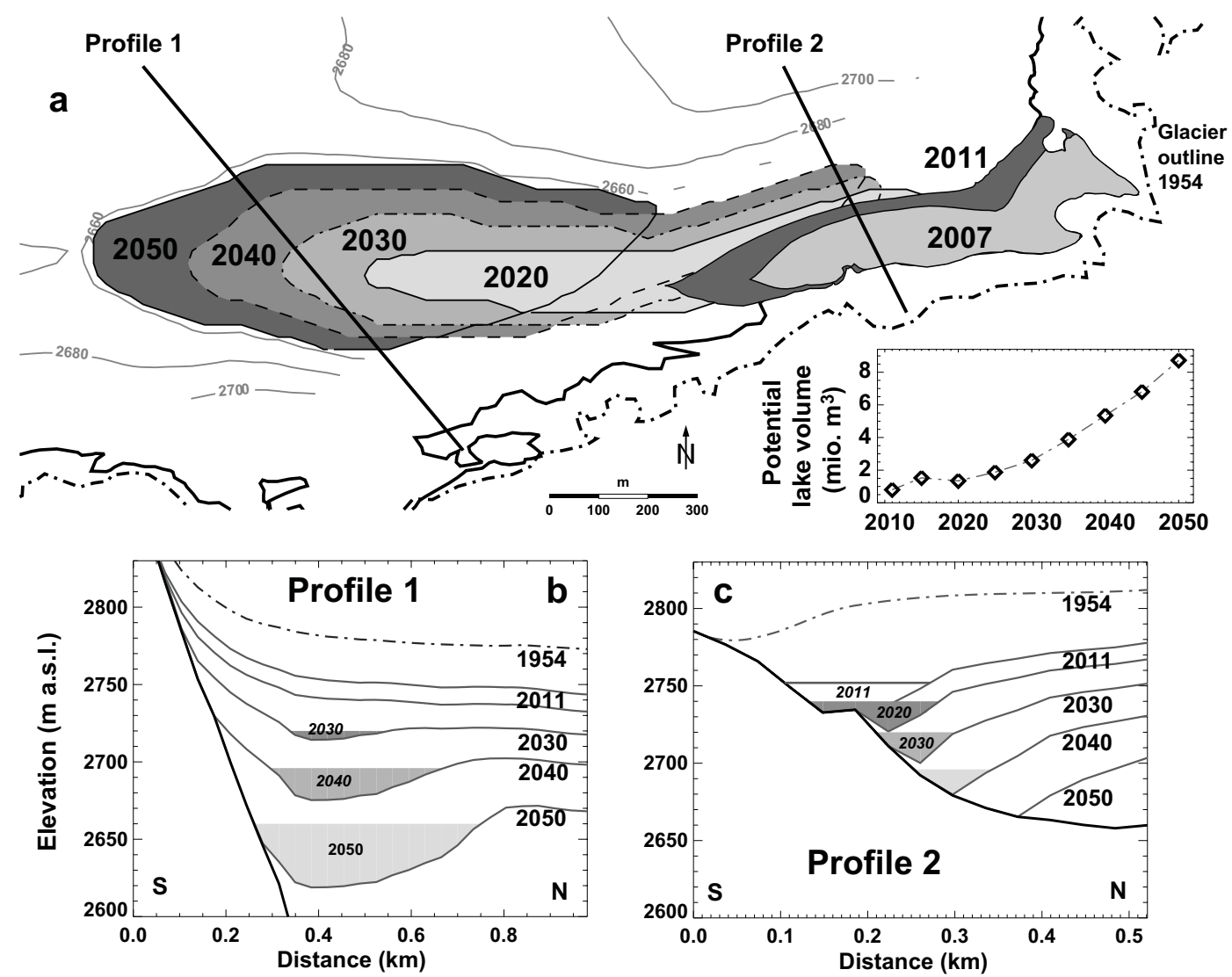

Figure 9. Simulated future changes in Lac des Faverges (Fig. 1a). (a) Map with observed lake extent in 2007 and 2011 , and modelled potential lake geometries in 2020, 2030, 2040 and 2050. Ice surface contours refer to the year 2050. The temporal changes in calculated lake volumes are given in the inset. $(\mathbf{b}, \mathbf{c})$ Two cross-profiles through Lac des Faverges with modelled glacier surfaces and lakes.

glacier response to climate change are still considerable. This is due to the spread in climate change scenarios, and several insufficiently understood feedback effects, such as possible changes in ice surface albedo hampering the reliability of our forecasts. Additional research on Glacier de la Plaine Morte is needed to enhance the understanding of glaciological processes that start to become relevant in the near future. This will also allow improving projections of changes in the natural hazard potential due to the outburst of glacier-dammed lakes and the implications for downvalley communities.

Acknowledgements. This study is funded within the NFP61 "Sustainable Water Management" (project number 125964) by the Swiss National Foundation, and the monitoring is supported by the Swiss Earth Observatory Network (SEON) since 2013. We are grateful to the numerous people that contributed to the collection of field data, in particular to M. Fischer and K. Naegeli. We thank N. Hählen, Oberingenieurkreis I, Thun, for providing the DEM for 2011 and their comments. Weather data were obtained from MeteoSwiss.

Edited by: E. Reynard

Reviewed by: two anonymous referees

\section{References}

Bauder, A., Funk, M., and Gudmundsson, G. H.: The ice thickness distribution of Unteraargletscher (Switzerland), Ann. Glaciol., 37, 331-336, 2003.

Bauder, A., Funk, M., and Huss, M.: Ice volume changes of selected glaciers in the Swiss Alps since the end of the 19th century, Ann. Glaciol., 46, 145-149, 2007.

Bavay, M., Gruenewald, T., and Lehning, M.: Response of snow cover and runoff to climate change in high Alpine catchments of Eastern Switzerland, Adv. Water Res., 55, 4-16, 2013.

Blindow, N., Suckro, S. K., Rückamp, M., Braun, M., Schindler, M., Breuer, B., Saurer, H., Simões, J. C., and Lange, M. A.: Geometry and thermal regime of the King George Island ice cap, Antarctica, from GPR and GPS, Ann. Glaciol., 51, 103-109, 2010.

Bosshard, T., Kotlarski, S., Ewen, T., and Schär, C.: Spectral representation of the annual cycle in the climate change signal, Hydrol. Earth Syst. Sci., 15, 2777-2788, doi:10.5194/hess-15-27772011, 2011.

Bou-Zeid, E., Higgins, C., Huwald, H., Meneveau, C., and Parlange, M. B.: Field study of the dynamics and modelling of subgridscale turbulence in a stable atmospheric surface layer over a glacier, J. Fluid Mech., 665, 480-515, 2010. 
Braun, L. N., Weber, M., and Schulz, M.: Consequences of climate change for runoff from Alpine regions, Ann. Glaciol., 31, 19-25, 2000.

Bühlmann, E.: Influence of particulate matter on observed albedo reductions on Plaine Morte glacier, Swiss Alps, M.Sc. thesis, University of Bern, 2011.

Bürki, R., Elsasser, B., and Abegg, B.: Climate change: Impacts on the tourism industry in mountain areas, Proceedings of the 1st International Conference on Climate Change and Tourism, Djerba, 9-11 April 2003.

Farinotti, D., Huss, M., Bauder, A., and Funk, M.: An estimate of the glacier ice volume in the the Swiss Alps, Global Planet. Change, 68, 225-231, 2009.

Farinotti, D., Usselmann, S., Huss, M., Bauder, A., and Funk, M.: Runoff evolution in the Swiss Alps: projections for selected highalpine catchments based on ENSEMBLES scenarios, Hydrol. Process., 26, 1909-1924, 2012.

Finger, D., Heinrich, G., Gobiet, A., and Bauder, A.: Projections of future water resources and their uncertainty in a glacierized catchment in the Swiss Alps and the subsequent effects on hydropower production during the 21 st century, Water Resour. Res., 48, W02521, doi:10.1029/2011WR010733, 2012.

Finger, D., Hugentobler, A., Huss, M., Voinesco, A., Wernli, H., Fischer, D., Weber, E., Jeannin, P.-Y., Kauzlaric, M., Wirz, A., Vennemann, T., Hüsler, F., Schädler, B., and Weingartner, R.: Identification of glacial meltwater runoff in a karstic environment and its implication for present and future water availability, Hydrol. Earth Syst. Sci., 17, 3261-3277, doi:10.5194/hess-17-32612013, 2013.

Fischer, A., Olefs, M., and Abermann, J.: Glaciers, snow and ski tourism in Austria's changing climate, Ann. Glaciol., 52, 89-96, 2011.

Funk, M. and Röthlisberger, H.: Forecasting the effects of a planned reservoir that will partially flood the tongue of Unteraargletscher in Switzerland, Ann. Glaciol., 13, 76-80, 1989.

Gabbi, J., Farinotti, D., Bauder, A., and Maurer, H.: Ice volume distribution and implications on runoff projections in a glacierized catchment, Hydrol. Earth Syst. Sci., 16, 4543-4556, doi:10.5194/hess-16-4543-2012, 2012.

Glaciological reports: The Swiss Glaciers, 1880-2006/07, Tech. Rep. 1-128, Yearbooks of the Cryospheric Commission of the Swiss Academy of Sciences (SCNAT), published since 1964 by Laboratory of Hydraulics, Hydrology and Glaciology (VAW) of ETH Zürich, 1881-2011.

Gross, G., Kerschner, H., and Patzelt, G.: Methodische Untersuchungen über die Schneegrenze in alpinen Gletschergebieten, Zeitschrift für Gletscherkunde und Glazialgeologie, 12, 223251, 1977.

Haeberli, W. and Beniston, M.: Climate change and its impacts on glaciers and permafrost in the Alps, Ambio, 27, 258-265, 1998.

Hählen, N.: Ausbruch Gletschersee Faverges, Oberingenieurkreis I, Tiefbauamt des Kantons Bern, Gemeinde Lenk, 2012.

Hock, R.: A distributed temperature-index ice- and snowmelt model including potential direct solar radiation, J. Glaciol., 45, 101$111,1999$.

Huggel, C., Allen, S., Deline, P., Fischer, L., Noetzli, J., and Ravanel, L.: Ice thawing, mountains falling - are alpine rock slope failures increasing?, Geology Today, 28, 98-104, 2012.
Huss, M.: Mass balance of Pizolgletscher, Geogr. Helv., 65, 80-91, doi:10.5194/gh-65-80-2010, 2010.

Huss, M.: Present and future contribution of glacier storage change to runoff from macroscale drainage basins in Europe, Water Resour. Res., 47, W07511, doi:10.1029/2010WR010299, 2011.

Huss, M.: Extrapolating glacier mass balance to the mountain-range scale: the European Alps 1900-2100, The Cryosphere, 6, 713727, doi:10.5194/tc-6-713-2012, 2012.

Huss, M., Bauder, A., Funk, M., and Hock, R.: Determination of the seasonal mass balance of four Alpine glaciers since 1865, J. Geophys. Res., 113, F01015, doi:10.1029/2007JF000803, 2008a.

Huss, M., Farinotti, D., Bauder, A., and Funk, M.: Modelling runoff from highly glacierized alpine drainage basins in a changing climate, Hydrol. Process., 22, 3888-3902, 2008b.

Huwald, H., Higgins, C. W., Boldi, M.-O., Bou-Zeid, E., Lehning, M., and Parlange, M. B.: Albedo effect on radiative errors in air temperature measurements, Water Resour. Res., 45, W08431, doi:10.1029/2008WR007600, 2009.

Huwald, H., Selker, J. S., Tyler, S. W., Calaf, M., van de Giesen, N. C., and Parlange, M. B.: Carbon monoxide as a tracer of gas transport in snow and other natural porous media, Geophys. Res. Lett., 39, L02504, doi:10.1029/2011GL050247, 2012.

Lehning, M., Loewe, H., Ryser, M., and Raderschall, N.: Inhomogeneous precipitation distribution and snow transport in steep terrain, Water Resour. Res., 44, W07404, doi:10.1029/2007WR006545, 2008.

Macheret, Y. Y., Moskalevsky, M. Y., and Vasilenko, E. V.: Velocity of radio waves in glaciers as an indicator of their hydrothermal state, structure and regime, J. Glaciol., 39, 373-384, 1993.

Maire, R.: Les karsts sous-glaciaires et leurs relations avec le karst profond, Rev. Geogr. Alp., 66, 139-148, 1978.

Oerlemans, J.: Glaciers and climate change, A. A. Balkema Publishers, 2001.

Paul, F., Machguth, H., and Kääb, A.: On the impact of glacier albedo under conditions of extreme glacier melt: the summer of 2003 in the Alps, EARSeL eProceedings, 4, 139-149, 2005.

Reynard, E. and Bonriposi, M.: Water use management in dry mountains of Switzerland. The case of Crans-Montana-Sierre area, in: The impact of urbanisation, industrial, agricultural and forest technologies on the natural environment, edited by: Neményi, M. and Balint, H., Sopron, Nyugatmagyarorszagi Egyetem, 281-301, 2012.

Röthlisberger, H.: Water pressure in intra- and subglacial channels, J. Glaciol., 11, 177-203, 1972.

Schaefli, B., Hingray, B., and Musy, A.: Climate change and hydropower production in the Swiss Alps: quantification of potential impacts and related modelling uncertainties, Hydrol. Earth Syst. Sci., 11, 1191-1205, doi:10.5194/hess-11-11912007, 2007.

Schneider, F. and Homewood, C.: Exploring water governance arrangements in the Swiss Alps from a perspective of adaptive capacity, Mt. Res. Dev., 33, 225-233, 2013.

Schotterer, U., Finkel, R., Oeschger, H., Siegenthaler, U., Wahlen, M., Bart, G., Gaggeler, H., and von Gunten, H. R.: Isotope measurements on firn and ice cores from alpine glaciers, Proc. Symp. Isotopes and Impurities in Snow and Ice, Grenoble 1975, IAHS, 118, 232-236, 1977.

Süsstrunk, A.: Sondage du glacier par la méthode sismique, La Houille Blanche, A, 309-318, 1951. 
Tsutaki, S., Nishimura, D., Yoshizawa, T., and Sugiyama, S.: Changes in glacier dynamics under the influence of proglacial lake formation in Rhonegletscher, Switzerland, Ann. Glaciol., 52, 31-36, 2011.

van der Linden, P. and Mitchell, J.: ENSEMBLES: Climate change and its impacts: Summary of research and results from the ENSEMBLES project, Tech. rep., Met Office Hadley Centre, FitzRoy Road, Exeter EX1 3PB, UK, 2009.

Voinesco, A.: Le glacier de la Plaine-Morte : Épaisseur de glace et bilan de masse, M.Sc. thesis, University of Fribourg, 2012.
Weingartner, R., Herweg, D., Liniger, H., Rist, S., Schädler, B., Schneider, F., Graefe, O., Hoelzle, M., and Reynard, E.: Options for sustainable water use in the Crans-Montana-Sierre region (Valais), MRI News, 5, 13-15, 2010.

Werder, M. A., Bauder, A., Funk, M., and Keusen, H.-R.: Hazard assessment investigations in connection with the formation of a lake on the tongue of Unterer Grindelwaldgletscher, Bernese Alps, Switzerland, Nat. Hazards Earth Syst. Sci., 10, 227-237, doi:10.5194/nhess-10-227-2010, 2010. 